\title{
Environmental Education After Sustainability : Hope in the Midst of Tragedy
}

\section{Pihkala, Panu Petteri}

2017-04-12

Pihkala , P P 2017 , ' Environmental Education After Sustainability : Hope in the Midst of Tragedy ', Global Discourse , vol. 7 , no. 1 , pp. 109-127 . https://doi.org/10.1080/23269995.2017.1300412

http://hdl.handle.net/10138/304383

https://doi.org/10.1080/23269995.2017.1300412

unspecified

acceptedVersion

Downloaded from Helda, University of Helsinki institutional repository.

This is an electronic reprint of the original article.

This reprint may differ from the original in pagination and typographic detail.

Please cite the original version. 


\section{Environmental Education After Sustainability:}

\section{Hope in the midst of Tragedy}

Revised version 30.11.2016 (Final version published in Global Discourse 7:1, 2017, 109-127)

Corresponding Author: Dr. Panu Pihkala, Faculty of Theology, University of Helsinki, Finland. ${ }^{1}$

Word count: 10,756 words

\footnotetext{
${ }^{1}$ Email: panu.pihkala@helsinki.fi
} 


\section{Abstract}

In this article, I discuss the challenge posed to environmental education (and education for sustainable development) by the thinkers who see the situation of the world as so severe that "sustainability" is an outdated concept. By environmental education I mean first of all educational activities for children and youth, but also environmental communication and action related to all age groups and methods.

My approach is interdisciplinary and I discuss especially the connections between environmental education and psychologies of the environment. Based on psychological research, I argue that the wide-scale unconscious anxiety, which people experience, should be taken very seriously in environmental education. My discussion thus contributes in a new kind of way to a long-standing key issue in environmental education, the gap between people's values and the perceived action. Scholars of eco-anxiety have argued that instead of not caring, many people in fact care too much, and have to resort to psychological defenses of denial and disavowal.

Thus, the question in environmental education is not anymore whether environmental education should deal with anxiety, for anxiety is already there. The question is how anxiety is dealt with; how unconscious anxiety is lured into daylight and processed in such a way as to generate positive action and resilience. The prevailing attitude in environmental education writing is right in emphasizing positive matters and empowerment, but the relation between hope and optimism must be carefully thought about and a certain sense of tragedy must be included. Therefore, my article participates in the discussion about the role of "fear appeals" in environmental education.

Drawing from my own field of expertise, religious studies and theology, I include discussion about the role of existential and spiritual factors in the phenomenon. I discuss deep themes such as anxiety, mortality, fear, hope, and joy. I provide ideas for activities, but the main point is to engage in thinking (and feeling) about the requirements and aims of environmental education in the current situation. Thus, my discussion is directed to anyone who wants to understand the reasons for inaction and the ways in which these may be overcome.

Keywords: environmental education; sustainability education; education for sustainable development; ecopsychology; conservation psychology; environmental ethics; hope and optimism; tragedy 


\section{Introduction}

People have different understandings of what environmental education (EE) is. Like the concept "education" itself, environmental education is often seen to refer to children and youth in particular. These age groups are in a major role in environmental education, but a wider view includes all age groups. A classic definition was made already in the late 1970s: "Environmental education should cater to all ages and socio-professional groups in the population" (Tbilisi Declaration 1977).

Thus defined, it is clear that environmental education is pursued in many areas and disciplines where the actual term is not used. A title of a recent book suggest this wider vision: Environmental Education and Advocacy (Johnson and Mappin [ed.] 2009). All activities which aim at shaping people's nature-relationships can be seen to have a dimension of environmental education. Even more widely, other activities can be analyzed for their implicit views on environmental education in the sense of asking what kind of views of human-nature-relationships they convey. Naturally there is a need for a focused and explicit EE, both as an academic discipline and a practice, but it is crucial to understand the wide nature of the issue.

During the last decades, when terminology related to sustainability has been popular, the term environmental education has often been replaced by "education for sustainable development" (ESD) and related terms, such as "sustainability education" and "education for sustainability" (Gough 2013, 13; cf. Berryman and Sauvé 2013; Sterling 2001). The use of terms has been related to differing views of education, environmental action and the balance between the needs of human communities and ecosystems, but also to more accidental factors such as the prevalence of a certain term and discipline in the institution where a certain scholar is educated or working. Similarities are found from the thoughts of people working under different terms for their fields. 
In this article, I discuss the challenge posed to environmental education by those thinkers who claim that we should stop using the term sustainability, because the global situation is so severe. This is one of the reasons that I use the term EE as a general concept, but I want to emphasize that my discussion is closely related to what many people call sustainable education. Other relevant terms include "climate change education" and "futures education". My main point is that environmental education (as widely understood) needs a realistic sense of tragedy. A major reason for this is the wide unconscious anxiety that people have. Hope and empowerment are still the responses to the situation, but the relation between hope and optimism must be clarified.

I will provide ideas and even outlines for practical activities, but the main point is to engage in thinking (and feeling) about the requirements and aims of EE in the current situation. My approach is interdisciplinary and I discuss especially the connections between EE and "psychologies of the environment", which I later call ecopsychology for brevity (for the various related terms, see Paidas 2011; Scott et al. 2016; Clayton and Myers 2015). This means that I discuss heavy themes such as anxiety and mortality, but also hope and joy.

As a result, some may think that my discussion is quite far from environmental education as it is often understood on a popular level: as practical activities where people learn how ecosystems function, care together for local environments, and so on. However, there has always been a wider dimension in thinking about EE, and in addition many of these deep themes have been implicitly present. I argue that in the current situation, we need more explicit and carefully thought-out treatment of them.

My discussion contributes in a rather new kind of way to a long-standing key issue in research on EE, the gap between people's values and the perceived action. While related psychological and to 
some extent existential factors have been somewhat discussed by scholars in EE (f.ex. Brownlee, Powell, and Hallo 2013; Selby 2011; Jickling and Wals 2008; Kollmuss and Agyeman 2002; cf. Stevenson et al. 2013, 514-515), I draw more extensively on the latest ecopsychological research on the scale and seriousness of unconscious anxiety as a factor which prevents positive action. This explains also the phenomenon that many people seem to be indifferent about climate change and related issues: the reason may be that instead of not caring, people in fact care too much, and resort to psychological defenses or paralyzing anxiety, apathy and helplessness. Thus, my article is related also to the discussion of "fear appeals" in EE.

Drawing from my own field of expertise, religious studies and theology, I discuss the role of existential and spiritual factors in the phenomenon. Some of the EE activities that I discuss have a general spiritual tone in the sense that they deal with the deep dimensions of existence and meaning. I argue that these kind of activities can be conducted either within or without a certain spiritual or religious tradition. However, I do believe, as some other scholars that I discuss here, that there are some "best practices" by spiritual and religious communities that can be very helpful in addressing the deep dimensions of EE in an age of crisis.

Among scholars working in the field of EE, I emphasize the importance of the work of David Hicks. It is fascinating that we have ended up in many similar views and recommendations: I knew Hicks' earlier work, but only after I had completed the first draft of this article did I read his Educating for Hope in Troubled Times (2014), which includes many similarities with my work. In the history of Hicks' work, there is a movement towards more caution as regards optimism and this is most evident in this latest book of his. Drawing from some of the similar sources that I do and from the famous EE thinker David Orr (2009), Hicks includes more pessimism about the future and argues for the need to deal with this situation in (environmental) education. I will refer to Hicks' 
work in many places in my article, but may it be said already here that a certain difference between our views is that I discuss tragedy and anxiety more, and I make a stronger difference between hope and optimism. The closest approach to mine is the one taken by Kelsey and Armstrong (2012).

My article, like Hicks' work, includes a strong dimension of futures education. As Hicks and Bord (2011), I emphasize the need for the performer of EE, the "environmental educator" or who I call a "leader", to engage in a personal process of dealing with visions of future (cf. Kelsey and Armstrong 2012, 197). In practice, this means wrestling with anxiety and the relation of despair and hope. By the term "leader" I do not wish to over-emphasize that role, for I believe in much of what theorists of constructive learning have argued, but I join those who argue that in times of crisis, including the climate crisis, the importance of good leadership turns crucial (Välimäki and Lehtonen 2009; Randall 2009, 126).

The psychoanalysts have pointed out that their possible insight into socio-environmental situations will most probably generate resistance, since that is the usual reaction when unconscious processes are called into daylight (Rustin 2013, 171). Hicks has discussed a similar kind of resistance that has arisen in connection with the ideas that he has been discussing $(2014,66)$. I expect that my deeper plunge into troubling issues, such as mortality, will probably meet resistance also, perhaps for various reasons. However, I hope that the challenge posed by the thinkers who I'm discussing would be carefully considered, perhaps over time if necessary.

Thus, my discussion is linked to several of the recognized needs for further research in EE (Stevenson et al. 2013), such as the role of emotions, hope and worldviews. I hope that my article will spark further discussion between various disciplines. For example, ecopsychologists rarely cite works in EE, even when they in practice discuss same themes. 


\section{Anxiety, Denial and Disavowal}

Even beyond the threat of nuclear warfare, I think, the ecological crisis is the greatest threat mankind collectively has ever faced ... My hypothesis is that man [sic] is hampered in his meeting of this environmental crisis by a severe and pervasive apathy which is based largely upon feelings and attitudes of which he is unconscious (Searles 1972).

Environmental education has always tried to balance between two things: a realistic account of the threats that the world is facing and an ethos which would motivate and empower people. Like many other environmental disciplines, EE has existed in essence for a long time, but it has been greatly strengthened since the late 1960s and the birth of the wider environmental movement (Gough 2013). In that movement, a major tenet has been consciousness about the severity of environmental problems and the possibility of a major crisis, even an apocalyptic one. It has remained a contested issue a) whether a major crisis is coming and b) how should information and fears about such a crisis be discussed (f.ex. Buell 1995, Chapter 9; cf. Skrimshire [ed.] 2010; Eckersley 2008).

Some have thought that it is only realistic to be serious about the threats and that the gravity of the situation will spark action. Others have pointed out that there is psychological evidence that "fear appeals" do not in general generate positive action, but may instead be counterproductive (see Dickinson et al. 2013; Marshall 2015, 138-144). In environmentalism, there has been much discussion and debate about this issue. As a result, many, indeed most, of those who wish to advance environmental matters (later: environmentalists ${ }^{1}$ ) have stressed that anxiety and guilt should not be generated (Lertzman 2015, 4; Weintrobe 2013a, 33). 
Thus, this is a key issue in environmental education, both in the specific field of EE and in the EE dimensions in all environmentalism. There are various major theories of EE, but practically all of them emphasize the need for a positive vision, where the individual is able to see that her actions can contribute to the state of things and thus can experience empowerment (Gough 2013; cf. Palmer 1998; Hungerford and Volk 1990). Educator David Sobel (1996) warns about generating "ecophobia" by discussing too many negative things related to environmental conditions (cf. Kelsey and Armstrong 2012, 187-188). Many scholars in both EE and psychology emphasize "optimism" as a key issue, in varying measure (Stevenson et al. 2013, 514; Clayton, Manning and Hodge 2014, 41; Fritze et al. 2008; Chang 2014, 107). Some have believed in technological solutions (cf. Huckle as quoted in Hicks 2002, 69).

However, two major and intertwined issues partly challenge this traditional understanding. First, if Clive Hamilton, John Foster and many others are right, the socio-environmental situation of the world is so severe that a major crisis is truly coming and indeed has already started. Second, these authors also point out that there is widespread denial and disavowal, because the crisis is so difficult to bear, and because it stands in opposition to a major traditional belief system, belief in progress (Hamilton [2011] 2015; Foster 2015; cf. Jamieson 2014). How should and could this situation be dealt with in EE? In Susan Koger's $(2015,246)$ words: "Somehow, we need to convey the urgency of the situation and engage and empower our audiences without overwhelming them or sending them into despair or retail therapy."

A starting point is to recognize and admit that it is difficult to think about these issues for leaders in EE also. Two recent popular but well researched books introduce the wide variety of factors which make it difficult for us deal with these questions. The titles are telling: What Are We Thinking When We Are Not Thinking About Climate Change (Stoknes 2015) and Don't Even Think About It: Why 
Our Brains are Wired to Ignore Climate Change (Marshall 2015). There are biological, social, psychological and political reasons for denial and disavowal. These two books make for excellent reading for both educators and educational activities (for youth and adults).

David Orr $(2009,184)$ tells that he has not met many educators who would be willing to consider the seriousness of the situation. This has direct links with the absence of activities related to emotions and existential themes in EE (Zeyer and Kelsey 2013; Kagawa and Selby [eds.] 2010; Kool and Kelsey 2006). Indeed, an emphasis on the importance of emotional preparation for teachers in climate change education is absent from many books, which usually stress the cognitive dimensions (cf. Chang 2014). A telling example is mentioned by Hicks $(2014,66)$ : when he proposed that the emotional dimension should be dealt with, an educator replied that "I don't expect to have to be a therapist in my work". However, as Macy and Johnstone $(2012,2)$ argue: "How can we even begin to tackle the mess we're in if we consider it too depressing to think about?"

Care must be taken in thinking about how to present troubling information (cf. Hicks and Bord 2001), but it is important to realize that the beginning of the conversation can also be relieving. One can start simply by asking himself and the audience: how do we feel about the socio-environmental situation of the world and about climate change? (To keep the text flowing, I shall often use the terms "climate change" or "crisis" to describe the wide socio-environmental crisis.) Questions and guidelines for both personal and group reflection are offered by Hicks (2014, 75-76, 88-89), as well as Macy and Johnstone (2012, 72, 76-78).

In other words, the environmental education leader should wrestle with the "difficult problem of anxiety" (term used by Weintrobe 2013a). I use the term anxiety both for a specific emotion and more widely: anxiety is linked to many other emotions, such as fear, helplessness, hatred, despair 
and depression (cf. Miceli and Castelfranchi 2010, 264-265). In psychological and psychoanalytical literature, there is now enlightening research and discussion about this phenomena (Clayton et al. 2015; Weintrobe [ed.] 2013; Nicholsen 2002), and I will discuss several aspects of it below. For its part, this research explains the inaction that is experienced in relation to climate change (cf. Brownlee, Powell and Hallo 2013; Gifford 2011). There is a grave need to help people to understand the scale and hiddenness of this anxiety, which is often called eco-anxiety. Philosopher Joanna Macy, who has developed many EE activities, has been a pioneer in discussing this “environmental despair” (1983, 1995).

The environmental crisis and climate change have both direct and indirect, gradual effects (Doherty and Clayton 2011; Clayton, Manning and Hodge 2014; cf. Weissbecker [ed.] 2011). The indirect effects are often difficult to notice for several reasons. First, they may happen gradually and avoid attention. Second, they are often unconscious. There is an increasing scholarly discussion about these indirect effects and I can only refer to some major tenets here. An illuminating comparison can be made to the threat of nuclear devastation and the research that has been conducted of people's reactions to it. Because these kind of problems are very difficult to solve and because they cause constant threat, people feel disempowered. Depression rates increase and especially the people who are, for various reasons, in a vulnerable position are prone to serious health effects, such as disorders and severe depression (Kidner 2007; Fritze et al. 2008; Doherty and Clayton 2011; Clayton, Manning and Hodge 2014).

There are various methods that people use to survive the anxiety. The best ways of adaptation are linked to positive action (cf. Randall 2009, 122-124; Reser and Swim 2011), but often the anxiety results in various forms of denial and disavowal as psychological defenses. Outright denialism is only one form of these (Stoknes 2015, 9-84; Foster 2015, Chapter 1). Psychoanalysts have warned 
that denial as disavowal may be more dangerous, because it builds a situation where reality both is and is not accepted. People find a way to live on their lives, ignoring the grave dangers even while information about them grows. Sally Weintrobe summaries the phenomenon:

- The reality has become too obvious to be simply denied with negation.

- There is anxiety that the damage is already too great to repair.

- There is felt to be not enough support and help to bear the anxiety and suffering that knowledge of reality brings (Weintrobe 2013a, 44).

Avoiding the subject of anxiety does not make people's anxieties about climate change go away. The defenses used to minimize anxieties drive them underground, where they are not worked through and can escalate. People need genuine emotional support to bear their anxieties... (46).

Environmental education thinkers Hicks and Bord (2001) have warned that leaders can make only things worse if they are not careful about the ways in which global problems are dealt with. There must be enough time and resources to engage the matters with the audience, and the audience must have opportunities for self-reflection and peer group work. Emotional support from the leaders is required (cf. Hicks 2014, Chapter 4, 173-176; Lehtonen, Cantell and Salonen 2016; Næss 2008). Otherwise, there is the danger that anxiety or the "wall of denial" only grows stronger (Stoknes 2015, 78).

A factor which proves the importance of such activities, and helps in them, is the fact that people do have a certain resonance with the situation. Weintrobe $(2013 a, 42)$ points out that "Deep down ... most people know this, at least unconsciously" (similarly Stoknes 2015, 7-8). Norgaard's study (2011) on the cultural forms on denial supports this: sometimes, the anxiety behind all the "acting" shows itself, for example late at night. My own experiences of discussing with people in Europe and North America confirm this, although I have collected no scientific data of these talks (cf. MoeLobeda 2013, 95-96). Roy Scranton argues strikingly: 
The problem with our response to climate change isn't a problem with passing the right laws or finding the right place for carbon or changing people's minds or raising awareness. Everybody already knows. The problem is that the problem is too big. The problem is that different people want different things. The problem is that nobody has real answers. The problem is that the problem is us. $(2015,68$, italics in original)

Thus, the question in environmental education is not anymore whether environmental education should deal with anxiety, for anxiety is already there (similar views in EE literature have been taken by Hicks 2014; Zeyer and Kelsey 2013; Kelsey and Armstrong 2012, 188-193; Selby 2011; Lehtonen 2015; cf. Forrest and Feder [eds.] 2011). The question is how anxiety is dealt with; how unconscious anxiety is lured into daylight and processed in such a way as to generate positive action and resilience. Despair and "doom and gloom" must not have the final word, but still the problems have to be faced. The prevailing attitude in EE writing is right in emphasizing positive matters and empowerment, but the relation between hope and optimism must be carefully thought about and a certain sense of tragedy must be included. I will return to this theme of hope after I have discussed several major facets related to this anxiety and the ways in which EE can function in relation to them.

\section{Mortality, Finitude and Fear}

A major source of eco-anxiety is fear related to the future: what will happen to us, our loved ones and nature? Some thinkers believe that fear is the key: people want to avoid it and those who want to use power use fear to control the masses (Wuthnow 2010; Pyszczynski 2004; cf. Klein 2007, 2014). Many thinkers have stressed that these fears are closely linked with mortality and finitude. Regarding climate change, people realize that it posits a danger of causing loss and even death. This is almost unbearable. As a result, people resort into denial and disavowal related to climate change. However, because anxiety is not dealt with, but instead it is repressed, it only gets worse (Foster 
2015; Marshall 2015, 205-210; Scranton 2015; Weintrobe 2013a, 42-43; Dickinson 2009;

Nicholsen 2002, esp. 108-112, 137-141; Pyszczynski, Greenberg and Solomon 1999).

The denial of death is an ancient issue and its role in technological societies has been deemed great (Becker 1973). Overly optimistic belief in the possibilities of science and technology can be seen as an effort to find a means to overcome mortality. The most extreme forms of transhumanism are current examples of this, and it should be kept in mind that several transhumanists are positive about climate engineering (and related notions, of which see Jamieson 2014, Chapter 7) as a means to deal with the mounting climate crisis (cf. Bonneuil 2015, 23-26). Foster (2015) links this with faith in progress: because people are too anxious about finitude, they resort to belief in progressivism.

Nicholsen (2002, 130-131) has raised up the important notion of "symbolic immortality" in relation to human-environment relations and eco-anxiety. Drawing on Robert J. Lifton's classic research, she discusses how people search for meaning by desiring that their life would continue to have significance after they have died. People wish that their lives would continue symbolically, which means a combination of actual continuation and metaphorical continuation, in various ways: either in their close ones (especially children), in the legacy of their work efforts, in the legacy of their artistic or creative efforts, in some kind of eternal life offered by religious faith, or, notably, in nature. I draw special attention to the last point: many people are comforted, often half-consciously, by the thought that nature, the ecosystems will go on, life will continue, and their bodies and actions will be transformed into particles in the lasting process of nature (cf. Weintrobe 2013b).

Now in the time of environmental crisis and the threat of atomic warfare, Nicholsen emphasizes, all these forms of symbolic immortality are threatened. Many people in industrialized countries do not 
find solace in the faiths of traditional religions (cf. Jamieson 2014, 200; Foster 2015, 111), and the environmental catastrophe threatens to take away all other aspects of symbolic immortality. This is why the situation is so traumatic and causes so much anxiety, Nicholsen argues (similarly, with different concepts, Weintrobe 2013b, 42-43; Steiner 2013, 81-82; Kidner 2007, 138).

If these thinkers are right, as I belief they are, if our fear of mortality causes anxiety which results in denial, disavowal and wrong types of environment-related behavior, then environmental education must in some way deal with this problem. Some may think that this goes beyond what EE is, but, given the situation, these deep issues have to be wrestled with, if anxiety is to be realized and burdens relieved. The two challenges for EE are:

- helping people realize how mortality is related to our fears, anxieties and denial of climate change, and

- helping people to come to grips with mortality, which is a source of empowerment and resilience.

However, the challenge is that when this issue of mortality is evoked, it can generate very strong emotions in audiences and even result in counterproductive action. Janis Dickinson, who has given deep thought to this issue, writes:

While climate change is a dire problem, one that is threatening to people's lifestyle, health, and survival, there is evidence that framing it within the context of threats, a strategy known as 'fear appeals,' can have the opposite of the intended effect. One suspected reason for this is that when asked to think about mortality people have a set of anxiety-buffering defenses that they subconsciously evoke ... (Dickinson et al. 2013, 147, emphasis mine) 
Others have noticed the same phenomenon: when confronted, people desperately cling on to the path that they have earlier chosen. It would be too painful to confront reality. Sometimes, it seems, this results in concentrating on work in a manner which suggests that implicitly work is for that person a major hope for symbolic immortality (cf. Hamilton [2011] 2015, 215-216).

Thus, dealing with mortality requires care, but it is of utmost importance. Explicitly death has been dealt with very little in environmental education, but implicitly it has been related to numerous facets of it. Some beginning have been made by Joshua Russell's recent article (2016), which focuses on children's experiences of deaths of companion animals. Russell explores "the cognitive, affective, and moral potential of an environmentally-centered death education" (13). I share Russell's interest on the theme and emphasize its relevance to eco-anxiety. Dealing with the mortality of animals is linked with dealing with our own mortality. It can also strengthen our understanding of interconnections between humans and other nature.

Mortality is an undercurrent in all futures education, although usually unconsciously. In addition, I think that EE has also implicitly helped people to deal with their mortality by strengthening their connections with natural environments, which people find therapeutic. What is needed now is more explicit integration of "education in mortality" with EE. Insights for this can be gained by reading Roy Scranton's Learning to Die in the Anthropocene (2015), which is an enlarged version of his much discussed writing in The New York Times. Drawing from his experiences as a soldier in the American-Iraq war, Scranton argues that we must retrieve the ancient task of philosophy (and, I would add, religion): dealing with mortality, accepting that we will die. In the line of Hamilton, Foster and others, Scranton discusses the severity of the environmental crisis and argues that in order to be able to live, we must first learn to die (cf. Foster 2015, 191-192). 
There are some studies in EE which admit that a careful use of "fear appeals" can provide positive results (Li 2014; cf. Dickinson et al. 2013; De Young 2013, 239). Harrison and Mallett (2013) argue that "mortality salience" can positively influence environmental behavior, if there is already some concern for it. Further research is evidently needed. However, what I am arguing here is that education in mortality can and should include gentle aspects, which makes it quite different from fear appeals as apocalyptic warnings.

What would such an environmental education be like? There is a need to develop it collectively, by listening to different voices and developing contextual methods. Along with fear and mortality, things that should be discussed and processed include grief, loss, guilt and shame; however, a deeper treatment of these themes must be left to another article. Some of the rudiments include: - the important role of natural environments, even parks or riversides in cities, as places where there is solace enough to engage oneself and others in encountering our mortality - the crucial role of wrestling with classics in arts and literature. As examples, I mention Shakespeare's The Tempest, Harry Martinson's Aniara, Albert Camus' The Plague (cf. the discussion about it in Hamilton 2013; Stoknes 2015, 225-226; Gibbons 2013ab), and the movie The Dead Poets' Society. The literature on ecocriticism offers insights for this (see Buell 2005; cf. Orr 2009, 192).

- the use of drama and art-based environmental education (see van Boeckel 2013). For example, Finnish art educators have conducted an activity for children in which they seek three items from nature: one related to birth, one to living and one to death (van Boeckel 2009, 147).

- the possibilities offered by spiritual (generally defined) activities and experiences (cf. Koger 2015; Selby 2011, 8; Christie 2013), such as: experiencing deeper connection with nature; burials of animals; and other ritual-type activities where mortality is encountered. Co-operation with various organizations, for example in the line of action research (see Stevenson and Robottom 2013), 
provides help in these kind of activities. One option is collaboration with various local spiritual communities and leaders (Ramsay and Manderson 2011; Hitzhusen 2012, 2011, 2007, 2006; Hitzhusen and Tucker 2013; Toh and Cavagas 2010).

\section{Tragedy}

Many environmentalists and environmental educators warn about using tragedy to describe the situation in the world. Philip Smith and Nicholas Howe argue in their insightful book, Climate Change as Social Drama (2015) that the narrative of tragedy tends to give a message that things are beyond the control of people. Like many other environmental thinkers, they see this as counterproductive.

On the other hand, many thinkers emphasize the gravity of the situation and either explicitly or implicitly discuss tragedy in its various forms. Among these thinkers, John Foster has given special attention to defining tragedy. In his view, events are made tragic not only because of the evil in them, but because of the ways in which even good intentions often have tragic consequences. Tragedy reveals troubling aspects of the structure of being itself and is thus closely linked to finitude. "Tragedy in the full sense arises when disaster ensues from and expresses destructive weaknesses which are inherent in the key life-strengths of an agent, whether an individual, an institution or, as in the present case, a mode of civilisation" (Foster 2015, 93, italics in original).

I think that Foster is right: we should stop and see the tragic elements of reality (cf. Eagleton 2015; McIntosh 2008). In addition, perhaps surprisingly for many, a sense of tragedy can help us to remain resilient. If we are honest, we see that massive forces in the human world contribute to the current crisis. Social structures can be made better, but it is very difficult, especially in the long run. Currently, the situation is that people are offered as a standard relatively small options for 
“greening” their lifestyles and making an impact (cf. Marshall 2015, 192-197; Stoknes 2015; Brulle and Dunlap 2015, 8-12). This can lead to what Sapiains, Beeton and Walker (2015) call “dissociative experience”. Many people feel social and personal (conscience-related) pressure to do something to alleviate the crisis. Even if they resort to the minor options that are available, they end up experiencing anxiety, because deep down they know that this is not enough. As a psychological defense they then tend to dissociate their own behavior and the actual demands of global situation (cf. Ojala 2012), ending up in a kind of neurotic behavior (cf. Lehtonen and Välimäki 2013). Another option is that they become depressed because they carry the whole world on their shoulders, which is a symptom many environmentalists have (Stoknes 2015, 88).

A sense of tragedy, together with various means for strengthening resilience, can allow us to face the reality: our actions, both personal and social, are inadequate. We are caught in a plight. We are both guilty and victims, which makes the situation both tricky (Nicholsen 2002, 142) and potentially relieving. This kind of tragic realism can alleviate anxiety, but further work is needed to address the question of hope, so that we do not end up in inaction or despair. The critics of the use of tragedy are right in saying that without hope, anxiety grows. This is closely related to the question of inevitability.

Some thinkers relate inevitability and necessity closely with tragedy and I think that the critique of the use of tragedy in EE is linked with this kind of view (cf. Smith and Howe 2015; MacLellan 2015, 52-53). However, there is a difference here between tragic drama and life. A tragic drama is a play, a setting of boundaries, an aspect of reality. Observing a tragic drama is a kind of a vaccination: it can provide health by injecting a suitable amount of the sickness in us and indeed reminding us that we have the potential for the sickness. At the same time, its role is to remind us of the good things that still remain, especially in contrast to the scenario that the tragic drama creates. 
If tragedy is the only and all-comprehensive narrative as related to climate change and the future of the world, then the critics of its use in EE are right: such a narrative is to be avoided. But tragedy has its important place as a reminder and exploration of key aspects of reality. It is the setting for “deep hope" (Hicks 2014, 106) or "realistic hope" (Orr 2009, 185). After all, one of the historical aims of tragedy has been to generate compassion (Wallace 2007, 5-6; Bushnell 2008).

\section{Hope, Meaning and Joy}

What is needed is hope in the midst of tragedy. It is important to note that the concepts "hope" and "optimism" are used in various ways, as is the adjective "hopeful" (Alarcon, Bowling and Khazon 2013; Scioli and Biller 2009; Webb 2007; McGeer 2004; Miceli and Castelfranchi 2010). I join those thinkers who argue that it is useful to separate hope and optimism in relation to the different views of future inherent in them. Optimism is linked with belief in a better future, often in “progress” (Foster 2015; Nicholsen 2002, 183; cf. Eagleton 2015). As David Orr (2009, 181-186) notes, optimism often generates good results, but it can sometimes be dangerous (cf. Scott et al. 2016, 190-191).

Hamilton ([2011] 2015, 129-133) discusses "illusions" and “delusions" as related to hope and optimism. "Positive illusions", referring to a famous book with the same title by Shelley Taylor, can be empowering and important for the psyche. However, there is a danger that they turn into harmful delusions, which enable people to avoid making necessary changes and choices. Even Martin Seligman, a guru of Positive Psychology, admits that when positive thinking is not able to change the future, people "must have the courage to endure pessimism" (131).

Hamilton himself (2013) suggests that the required attitude is "pessimism of strength" or "active nihilism" (28, borrowing the last concept from Nietzsche). Personally, I join those who see that the 
concept of hope has much possibilities for EE. Hope is a powerful word, it has a long history and it has an implicit relation to tragedy and finitude, even when this has to be discussed and brought into daylight (Scioli and Biller 2009). Webb's (2007) discussion of five different "modes of hoping" is important reading for environmental educators: in the proposals about hope made by various thinkers, there is manifested a certain variety of views of hope, such as patient hope and utopian hope.

The crucial point is that hope can be strongly related to a process of creating meaning and positive action, not so much to a certain goal or state of the future (cf. Clayton \& Myers 2009, 204-205; Jamieson 2014, 237-238). Naturally a vision is needed, but the difference between hope and optimism is that hope can prevail even when there is no certainty at all about the future. This is the "radical hope" that philosopher Jonathan Lear and educators Orr and Hicks champion: "it is directed toward a future goodness that transcends the current ability to understand what it is. Radical hope anticipates a good for which those who have the hope as yet lack the appropriate concepts with which to understand it" (Lear as quoted in Orr 2009, 173 and Hicks 2014, 109; cf. Williston 2012).

Foster $(2015,17)$ takes a very similar view and argues that: "the opposite of despair is not optimism ... but hope". Hope is a conviction that there is still something worthwhile; contrary to despair, which believes that there is nothing left. There is a possibility for something more honest, more resilient; it may not be "better" in the modern sense of "progress", but still a step forward in another sense. As Orr notes $(2009,181-185)$, there is sometimes a tenet in optimism that achieving a better future is relatively easy; he and the other advocates of "deep hope" point out that it will be very difficult. One could say that for them (and me) hope is a virtue, a habit of finding meaning and 
resilience, not giving up. Hope "can mean the clear-eyed determination to live anyway" (Foster 2015, 92).

Several other thinkers agree. Macy and Johnstone (2012, 3) champion "active hope", which does not require optimism and can be practiced even when we feel hopeless. Stoknes $(2015,220-222)$ emphasizes "active pessimism" and "grounded hope": "It's hopeless and I'll give it my all", he summarizes.

However, it takes courage to encounter reality and to be able to hope (Orr 2009, 173, 184-185; van Boeckel 2009, 158; in theology, see Tillich 1965, 1952). This is a tough challenge for leaders in education and advocacy. The leaders must have the courage to engage in working with the "affective and existential" dimensions of the situation (cf. Hicks and Bord 2001, 424).

Even despair can contain seeds of hope, as James Hillman and several others have pointed out (Stoknes 2015, 188-189, 219; Nicholsen 2002, 183-185; Hicks 2014, 106-109). Separation of hope from a certain clearly defined state of the future helps also to avoid what McGeer $(2004,110-111)$ calls "willful hope", which often results in using others only as tools to advance one's goals, and in depression if the result is not achieved. Orr $(2009,189-190)$ compares the certain heart-breaking situation that realism brings with a situation of a doctor who knows how serious a perceived illness is: the patient must be told, and as a result, surprising courage and determination often occurs. As pointed out above, this requires that the teacher, the environmental educator, must first process these things herself.

In research on EE, the studies by Ojala $(2016,2012,2007)$ confirm the crucial importance of hope for people living in our times. Ojala's studies focus on young people, who are an excellent source, 
because many of them have not yet resorted to forms of denial. Many studies have revealed that youth experience much anxiety about the global situation. As a needed response to the situation, Ojala (2012) defines three main themes for what she calls "constructive hope", as differentiated from "hope" as denial, which means wishful thinking (cf. McGeer 2004). Based on the analysis of interviews, people needed "positive re-appraisal", the ability to see something meaningful and promising after encountering the situation of the world. This was often related to "trust in sources outside oneself": people wanted and often needed to believe that there are forces and institutions which are working towards good. And finally, people needed “trust in one's own ability to influence environmental problems in a positive direction".

Ojala does not discuss tragedy per se, but a discussion with her results provides an example about the ways in which hope and tragedy can be combined. She notes that hope gives "energy to act even in the absence of certainties" (Ojala 2012, 627). This absence and its tragic character can be strengthened in relation to the three main themes she describes. Positive re-appraisal can be linked with creating meaning, stressing hope and not optimism. Ojala herself notes that trust in others is not necessarily well-founded or beneficial for environmental responsibility, for it can be a form of externalizing action to others (628). Thirdly, the trust in one's own ability to influence environmental problems in a positive direction can be interpreted as development of resilience: the positive direction need not be "progress" in the traditional sense, but a more honest, meaningful and resilient situation (cf. Hicks 2002, 76-77).

Many people, deep down, resonate with the need for a realistic hope. They are aware that there are no easy solutions to the vast problems (cf. Marshall 2015, 145-149; Smith and Howe 2015, 199200). Realistic hope has its discomforting elements, but it can also be deeply relieving for teachers, for example. Many teachers who have the task of dealing with climate education have struggled 
with the problem of anxiety, despair and hope (cf. Kelsey and Armstrong 2012, 189). They have the idea that they must not express their anxieties to children and youth, for that would generate despair (Hamilton [2011] 2015, 129). These warnings, which are often found in climate education materials, are relevant in the sense that the teacher must be careful not to project her anxieties to children (Österlind 2012, 46); and it should be kept in mind that the relations between the generations are a tricky issue psychologically (cf. Nicholsen 2002, 11, 135).

However, realistic discussion, where both tragedy and hope are dealt with, can be empowering for both the teacher and the audience. As discussed above, there is already anxiety that should be dealt with. Dickinson et al. $(2013,156)$ argue: "If psychological resilience in the face of dire problems is a matter of tolerating increased anxiety, rather than suppressing it, then a combination of empowerment (collective efficacy) with compassion for other organisms may be a favorable emotional outcome of climate change education." As Kelsey and Armstrong (2012), I argue that environmental education must build on hope as resilience.

Hicks provides many practical recommendations for educators in relation to discussing realistic hope $(2014,70-77,85-90,100-104,144-146)$. His research of the "sources of hope" for people has provided an important list of things to be grateful of (110-120; cf. Macy and Johnstone 2012, Chapter 3; Kelsey [ed.] 2014). This points to a crucial dimension of joy and play, which may sound somewhat absurd after all the discussion above about anxiety, grief and other heavy matters. However, some of the most profound joy is found from places and people who have a strong sense of the tragic: that has helped them to appreciate daily life and ordinary things, and realistic hope can bring empowerment (cf. Stoknes 2015, 188-189). 
Basically, there are two possibilities to respond to mortality and all that it contains: one can despair of the brevity of time (cf. Sigmund Freud on transience, quoted in Lertzman 2013, 124-126) or one can practice the art of carpe diem, living in the present. Writers such as Annie Dillard (1974) and Rachel Carson (1965) have written eloquently of the joy that a sense of wonder and a capacity to remain open to the world, despite the pain involved, can bring (cf. Foster 2015, 97-98, 109-110). As Carson's example shows, such an attitude can be strongly linked with positive action. A third writer, Vaclav Havel condensed some elementary aspects of such an attitude in his discussion of hope:

Hope ... is not prognostication. It is an orientation of the spirit, an orientation of the heart; it transcends the world that is immediately experienced, and is anchored somewhere beyond its horizons ... Hope, in this deep and powerful sense, is not the same as joy that things are going well, . . but, rather, an ability to work for something because it is good (quoted in Orr 2009, 182).

Others have described this kind of attitude by emphasizing the importance of retaining an ability to play well (cf. Clayton and Myers 2015, 295-296). Theologian Hugo Rahner goes so far as to say that only a homo ludens, the human at play, is able to take in both the tragedy and the joy. He seeks to describe "that attitude that is poised between gaiety and gravity, between mirth and tragedy, and which the Greeks designated by the inimitable expression ... the "grave-merry" man. Such a man [sic] is capable of making his life into a game, and a very lovely one at that, because he knows that this life is either a comedy or tragedy" (Rahner 1972, 9).

Thus, there is a link to "well-being" and "happiness" (cf. Weissbecker [ed.] 2011; Kelsey and Armstrong 2012) in my argument, but I emphasize the need to encounter the tragic situation realistically. The way in which I would frame the narrative for our socio-environmental situation (cf. Smith and Howe 2015) is not melodrama and neither a simple tragedy, but a combination of 
tragedy and hope. It should be noted here that some thinkers use the concept of optimism in ways which come close to what I have discussed as hope. Examples include the application of Victor Frankl's "tragic optimism" as meaning-creating activity which builds resilience (Ramsay and Manderson 2011, 168-171), Hicks's “cautious optimism” $(2014,175)$ and the "dark optimism" discussed by Hoggett (2013).

A somewhat similar stance is taken by one of the most influential environmental thinkers of the twentieth century, Aldo Leopold (1886-1948), who provided pioneering reflections on environmental education also. He believed that "fear and indignation" are not the ways in which children and youth should be educated. Manifesting what has been called above "realistic hope", Leopold ([1955] 1993) stated that: "we shall not achieve harmony with land, any more than we shall achieve justice or liberty for people. In these higher aspirations, the important point is not to achieve, but to strive" (155-157).

It's a tough task. But an honest one, and one much needed.

\section{Abbreviations}

EE Environmental education

ESD Education for Sustainable Development

\section{Acknowledgements}

I express gratitude for comments on the draft of this article by EE scholars Anna Lehtonen and Essi AarnioLinnanvuori. 


\section{References}

Alarcon, Gene M., Nathan A. Bowling, and Steven Khazon. 2012. "Great Expectations: A MetaAnalytic Examination of Optimism and Hope." Personality and Individual Differences 54 (7): 821-827.

Becker, Ernest. 1973. The Denial of Death. New York: Free Press.

Berryman, Tom and Lucie Sauvé. 2013. "Languages and Discources of Education, Environment, and Sustainable Development." In International Handbook of Research on Environmental Education, edited by Robert B. Stevenson, Michael Brody, Justin Dillon and Arjen E. J. Wals, 133-146. New York \& London: Routledge.

Boeckel, Jan van. 2009. "Arts-Based Environmental Education and the Ecological Crisis: Between Opening the Senses and Coping with Psychic Numbing." In Metamorphoses in children's Literature and Culture, edited by Barbara Drillsma-Milgrom and Leena Kirstinä, 145-164. Turku: Enostone.

Boeckel, Jan van. 2013. At the Heart of Art and Earth: An Exploration of Practices in Arts-Based Environmental Education. Dissertation. Helsinki: Aalto University, School of Arts, Design and Architecture.

Bonneuil, Christophe. 2015. "The Geological Turn: Narratives of the Anthropocene." In The Anthropocene and the Global Environmental Crisis: Rethinking Modernity in a New Epoch, edited by Clive Hamilton, Christophe Bonneuil and Francois Gemenne, 17-31. London and New York: Routledge.

Brownlee, Matthew T. J., Robert B. Powell, and Jeffery C. Hallo. 2013. "A Review of the Foundational Processes that Influence Beliefs in Climate Change: Opportunities for Environmental Education Research." Environmental Education Research 19 (1): 1-20.

Brulle, Robert J. and Riley E. Dunlap. 2015. "Sociology and Global Climate Change." In Climate Change and Society: Sociological Perspectives, edited by Riley E. Dunlap and Robert J. Brulle, 1-30. New York: Oxford University Press.

Buell, Lawrence. 1995. The Environmental Imagination: Thoreau, Nature Writing, and the Formation of American Culture. Cambridge: Belknap.

Buell, Lawrence. 2005. The Future of Environmental Criticism: Environmental Crisis and Literary Imagination. Blackwell Manifestos. Malden: Blackwell.

Bushnell, Rebecca. 2008. Tragedy: A Short Introduction. Blackwell Introductions to Literature 18. Malden: Blackwell.

Carson, Rachel. 1965. The Sense of Wonder. New York: Harper \& Row. 
Chang, Chew Hung. 2014. Climate Change Education: Knowing, Doing and being. Oxfordshire, England: Routledge.

Christie, Douglas E. 2013. The Blue Sapphire of the Mind: Notes for a Contemplative Ecology. New York: Oxford University Press.

Clayton, Susan, Christie Manning, and Caroline Hodge. 2014. Beyond Storms \& Droughts: The Psychological Impacts of Climate Change. Washington, DC: APA and ecoAmerica. Clayton, Susan and Gene Myers. 2015. Conservation Psychology Understanding and Promoting Human Care for Nature. Second ed. West Sussex: John Wiley \& Sons Ltd.

Clayton, Susan and Gene Myers. 2009. Conservation Psychology: Understanding and Promoting Human Care for Nature. First ed. Chichester: Wiley-Blackwell.

Clayton, Susan, Patrick Devine-Wright, Paul Stern, Lorraine Whitmarsh, Amanda Carrico, Linda Steg, Janet Swim, and Mirilia Bonnes. 2015. "Psychological Research and Global Climate Change." Nature Climate Change 5 (7): 640-646.

Clinebell, Howard John. 1996. Ecotherapy: Healing Ourselves, Healing the Earth: A Guide to Ecologically Grounded Personality Theory, Spirituality, Therapy, and Education. Minneapolis: Fortress Press.

Dickinson, Janis L. 2009. "The People Paradox: Self-Esteem Striving, Immortality Ideologies, and Human Response to Climate Change." Ecology \& Society 14 (1): 1-17.

Dickinson, Janis L., Rhiannon Crain, Steve Yalowitz, and Tammy M. Cherry. 2013. "How Framing Climate Change Influences Citizen Scientists' Intentions to do Something about it." Journal of Environmental Education 44 (3): 145-158.

Dillard, Annie. 1974. Pilgrim at Tinker Creek. New York: Harper's Magazine Press.

Doherty, Thomas J. and Susan Clayton. 2011. "The Psychological Impacts of Global Climate Change." American Psychologist 66 (4): 265-76.

Eagleton, Terry. 2015. Hope without Optimism. Charlottesville and London: University of Virginia Press.

Eckersley, Richard. 2008. "Nihilism, Fundamentalism, or Activism: Three Responses to Fears of the Apocalypse." Futurist 42 (1): 35-39.

Forest, Sherrie and Michael A. Feder. 2011. Climate Change Education: Goals, Audiences, and Strategies: A Workshop Summary National Academies Press.

Foster, John. 2015. After Sustainability: Denial, Hope, Retrieval. London and New York: Routledge. 
Fritze, Jessica, Grant A. Blashki, Susie Burke and John Wiseman. 2008. "Hope, Despair and Transformation: Climate Change and the Promotion of Mental Health and Wellbeing." International Journal of Mental Health Systems 2 (1): 13.

Gibbons, Andrew. 2013a. "The Teaching of Tragedy: Narrative and Education.” Educational Philosophy \& Theory 45 (11), 1150-1161.

Gibbons, Andrew. 2013b. “Tragedy and Teaching: The Education of Narrative.” Educational Philosophy \& Theory 45 (11), 1162-1174.

Gough, Annette. 2013. "The Emergence of Environmental Education Research." In International Handbook of Research on Environmental Education, edited by Robert B. Stevenson, Michael Brody, Justin Dillon and Arjen E. J. Wals, 13-22. New York \& London: Routledge. Hamilton, Clive. (2011) 2015. Requiem for a Species: Why we Resist the Truth about Climate Change. New York: Earthscan.

Hamilton, Clive. 2013. "What History can Teach Us about Climate Change Denial." In Engaging with Climate Change: Psychoanalytic and Interdisciplinary Perspectives, edited by Sally Weintrobe, 16-32. London and New York: Routledge.

Hamilton, Clive, Christophe Bonneuil, and Francois Gemenne, eds. 2015. The Anthropocene and the Global Environmental Crisis. London: Routledge.

Harrison, Patrick R. and Robyn K. Mallett. 2013. "Mortality Salience Motivates the Defense of Environmental Values and Increases Collective Ecoguilt." Ecopsychology 5 (1): 36-43.

Hicks, David. 2014. Educating for Hope in Troubled Times: Climate Change and the Transition to a Post-Carbon Future. London: Institute of Education Press.

Hicks, David. 2002. Lessons for the Future: The Missing Dimension in Education. Futures and Education Series. London: Routledge.

Hicks, David and Andy Bord. 2001. "Learning about Global Issues: Why Most Educators Only Make Things Worse." Environmental Education Research 7 (4): 413-425.

Hitzhusen, Gregory E. 2011. "Climate Change Education for Faith Based Groups." Unpublished Manuscript. Ohio State University.

Hitzhusen, Gregory E. 2012. "Going Green and Renewing Life: Environmental Education in Faith Communities." New Directions for Adult and Continuing Education 133 (Spring): 35-44. Hitzhusen, Gregory E. 2007. "Judeo-Christian Theology and the Environment: Moving Beyond Scepticism to New Sources for Environmental Education in the United States." Environmental Education Research 13 (1): 55-74.

Hitzhusen, Gregory E. 2006. "Religion and Environmental Education: Building on Common Ground." Canadian Journal of Environmental Education 11 (1): 9-25. 
Hitzhusen, Gregory E. and Mary Evelyn Tucker. 2013. "The Potential of Religion for Earth Stewardship." Frontiers in Ecology and the Environment 11 (7): 368-376.

Hoggett, Paul. 2013. "Discussion: Climate Change in a Perverse Culture." In Engaging with Climate Change: Psychoanalytic and Interdisciplinary Perspectives, edited by Sally Weintrobe, 84-86. London and New York: Routledge.

Hungerford, Harold R. and Trudi L. Volk. 1990. "Changing Learner Behavior through Environmental Education." The Journal of Environmental Education 21 (3): 8-21.

Jamieson, Dale. 2014. Reason in a Dark Time: Why the Struggle Against Climate Change Failed-and what it Means for our Future. Oxford: Oxford University Press.

Jickling, Bob and Arjen E. J. Wals. 2008. "Globalization and Environmental Education: Looking Beyond Sustainable Development." Journal of Curriculum Studies 40 (1): 1-21.

Johnson, Edward A. and Michael J. Mappin. 2009. Environmental Education and Advocacy: Changing Perspectives of Ecology and Education Cambridge University Press.

Kagawa, Fumiyo and David Selby. 2010. Education and Climate Change: Living and Learning in Interesting Times Routledge.

Kelsey, Elin, ed. 2014. Beyond Doom and Gloom: An Exploration through Letters. Munich: RCC. Kelsey, Elin and Carly Armstrong. 2012. "Finding Hope in a World of Environmental Catastrophe." In Learning for Sustainability in Times of Accelerating Change, edited by Arjen E. J. Wals and Peter Blaze Corcoran, 187-200. Netherlands: Wageningen Academic Pub.

Kevorkian, Kristine A. 2004. "Environmental Grief: Hope and Healing." Dissertation, Union Institute \& University.

Kidner, David W. 2007. "Depression and the Natural World: Towards a Critical Ecology of Psychological Distress." Critical Psychology (19): 123.

Klein, Naomi. 2007. The Shock Doctrine: The Rise of Disaster Capitalism. New York: Metropolitan Books/Henry Holt.

Klein, Naomi. 2014. This Changes Everything: Capitalism Vs. the Climate. London: Penguin. Koger, Susan M. 2015. "A Burgeoning Ecopsychological Recovery Movement." Ecopsychology 7 (4): 245 .

Kollmuss, Anja and Julian Agyeman. 2002. "Mind the Gap: Why do People Act Environmentally and what are the Barriers to Pro-Environmental Behavior?" Environmental Education Research 8 (3): 239-260.

Kool, Rick and Elin Kelsey. 2006. "Dealing with Despair: The Psychological Implications of Environmental Issues." In Innovative Approaches to Education for Sustainable 
Development, edited by Walter Leal Filho and Mario Salomone, 193-202. Frankfurt: Peter Lang.

Lehtonen, Anna. 2015. "Calls for Creative Collaboration: How can Drama Provide Creative and Collaborative Learning Methods for Climate Change Education?" Nordisk Dramapedagogisk Tidskrift 52 (3): 34-37.

Lehtonen, Anna, Hannele Cantell, and Arto Salonen. 2017. "Climate Change Education: New Approach for the World of Wicked Problems (Forthcoming)." Sitra.

Lehtonen, Johannes and Jukka Välimäki. 2013. "The Environmental Neurosis of Modern Man: The Illusion of Autonomy and the Real Dependence Denied." In Engaging with Climate Change: Psychoanalytic and Interdisciplinary Perspectives, edited by Sally Weintrobe, 4851. London: Routledge.

Leopold, Aldo. (1955) 1993. Round River: From the Journals of Aldo Leopold. Oxford and New York: Oxford University Press.

Leopold, Aldo. 1949. A Sand County Almanac and Sketches here and there. New York: Oxford University Press.

Lertzman, Renée Aron. 2015. Environmental Melancholia: Psychoanalytic Dimensions of Engagement. Hove and New York: Routledge.

Lertzman, Renée Aron. 2013. "The Myth of Apathy: Psychoanalytic Explorations of Environmental Subjectivity." In Engaging with Climate Change: Psychoanalytic and Interdisciplinary Perspectives, edited by Sally Weintrobe, 117-133. London and New York: Routledge.

MacLellan, Matthew. 2015. "The Tragedy of Limitless Growth: Re-Interpreting the Tragedy of the Commons for a Century of Climate Change." Environmental Humanities 7 (2): 41-58.

Macy, Joanna. 1983. Despair and Personal Power in the Nuclear Age. New Society Publishers: Philadelphia.

Macy, Joanna. 1995. "Working through Environmental Despair." In Ecopsychology: Restoring the Earth, Healing the Mind, edited by Theodore Roszak, Mary E. Gomes and Allen D. Kanner, 240-269. San Francisco: Sierra Club.

Macy, Joanna and Chris Johnstone. 2012. Active Hope: How to Face the Mess we'Re in without Going Crazy. Novato: New World Library.

Marshall, George. 2015. Don't Even Think about it: Why our Brains are Wired to Ignore Climate Change. New York: Bloomsbury Publishing USA.

McGeer, Victoria. 2004. "The Art of Good Hope." The Annals of the American Academy of Political and Social Science 592: 100-127. 
McIntosh, Alastair. 2008. Hell and High Water: Climate Change, Hope and the Human Condition. Edinburgh: Birlinn.

Miceli, Maria and Cristiano Castelfranchi. 2010. "Hope: The Power of Wish and Possibility." Theory \& Psychology 20 (2): 251-276.

Moe-Lobeda, Cynthia D. 2013. Resisting Structural Evil: Love as Ecological-Economic Vocation. Minneapolis: Fortress Press.

Næss, Arne. 2002. Life's Philosophy: Reason and Feeling in a Deeper World. Athens: University of Georgia Press.

Nicholsen, Shierry Weber. 2002. The Love of Nature and the End of the World: The Unspoken Dimensions of Environmental Concern. Cambridge: MIT Press.

Norgaard, Kari Marie. 2011. Living in Denial: Climate Change, Emotions, and Everyday Life. Cambridge: MIT Press.

Ojala, Maria. 2012. "Hope and Climate Change: The Importance of Hope for Environmental Engagement among Young People." Environmental Education Research 18 (5): 625-642.

Ojala, Maria. 2007. "Hope and Worry: Exploring Young People's Values, Emotions, and Behavior regarding Global Environmental Problems." Örebro University: Universitetsbiblioteket.

Ojala, Maria. 2016. "Young People and Global Climate Change: Emotions, Coping, and Engagement in Everyday Life." In Geographies of Global Issues: Change and Threat, edited by Nicola Ansell, Natascha Klocker and Tracey Skelton, 1-19. Singapore: Springer.

Orr, David W. 2009. Down to the Wire: Confronting Climate Collapse. Oxford: Oxford University Press.

Österlind, Eva. 2012. "Emotions - Aesthetics - Education: Dilemmas Related to Students' Commitment in Education for Sustainable Development." Journal of Artistic and Creative Education 6 (1): 32-50.

Paidas, Stephanie M. 2011. "Psychologies of the Environment: Searching for Themes in the Literature." Ecopsychology 3 (2): 125-138.

Palmer, Joy A. 1998. Theory of Environmental Education. Florence, KY, USA: Routledge. Pyszczynski, Tom. 2004. "What are we so Afraid of? A Terror Management Theory Perspective on the Politics of Fear." Social Research 71 (4): 827-848.

Pyszczynski, Tom, Jeff Greenberg, and Sheldon Solomon. 1999. "A Dual-Process Model of Defense Against Conscious and Unconscious Death-Related Thoughts: An Extension of Terror Management Theory." Psychological Review 106 (4): 835-845.

Rahner, Hugo. 1972. Man at Play. New York: Herder and Herder. 
Ramsay, Tamasin and Lenore Manderson. 2011. "Resilience, Spirituality and Posttraumatic Growth: Reshaping the Effects of Climate Change." In Climate Change and Human Wellbeing: Global Challenges and Opportunities, edited by Inka Weissbecker, 165-184. New York: Springer.

Randall, Rosemary. 2013. "Great Expectations: The Psychodynamics of Ecological Debt." In Engaging with Climate Change: Psychoanalytic and Interdisciplinary Perspectives, edited by Sally Weintrobe, 87-102. London and New York: Routledge.

Randall, Rosemary. 2009. "Loss and Climate Change: The Cost of Parallel Narratives." Ecopsychology 1 (3): 118-129.

Reser, Joseph P. and Janet K. Swim. 2011. "Adapting to and Coping with the Threat and Impacts of Climate Change." American Psychologist 66 (4): 277-89.

Riebel, Linda. 2015. "Creativity and the Long Emergency." Ecopsychology 7 (4): 238-244.

Russell, Joshua. 2016. "'Everything Has to Die One Day:' Children's Explorations of the Meanings of Death in Human-Animal-Nature Relationships." Environmental Education Research 4.2.2016: 1-16 (10.1080/13504622.2016.1144175).

Rustin, Michael. 2013. "How is Climate Change an Issue for Psychoanalysis?" In Engaging with Climate Change: Psychoanalytic and Interdisciplinary Perspectives, edited by Sally Weintrobe, 170-185. London and New York: Routledge.

Sapiains, Rodolfo, Beeton, Robert J. S. \& Walker, Iain A. 2015. “The Dissociative Experience: Mediating the Tension between People's Awareness of Environmental Problems and their Inadequate Behavioral Responses." Ecopsychology 7 (1): 38-47.

Scioli, Anthony and Henry B. Biller. 2009. Hope in the Age of Anxiety. Oxford and New York: Oxford University Press.

Scott, Britain A., Elise L. Amel, Susan M. Koger, and Christie M. Manning. 2016. Psychology for Sustainability. New York: Routledge.

Scranton, Roy. 2015. Learning to Die in the Anthropocene: Reflections on the End of a Civilization. San Francisco: City Lights Publishers.

Searles, Harold. 1972. "Unconscious Processes in Relation to the Environmental Crisis." Psychoanalytic Review 59 (3): 361-374.

Selby, David E. 2011. "Education for Sustainable Contraction as Appropriate Response to Global Heating." Journal for Activist Science and Technology Education 3 (1): 1-14.

Shapiro, Elan. 1995. "Restoring Habitats, Communities, and Souls." In Ecopsychology: Restoring the Earth, Healing the Mind, edited by Theodore Roszak, Mary E. Gomes and Allen D. Kanner, 224-239. San Francisco: Sierra Club. 
Skrimshire, Stefan, ed. 2010. Future Ethics: Climate Change and Apocalyptic Imagination. London: Bloomsbury Publishing.

Smith, Philip and Nicolas Howe. 2015. Climate Change as Social Drama: Global Warming in the Public Sphere. Cambridge: Cambridge University Press.

Sobel, David. 1996. Beyond Ecophobia: Reclaiming the Heart in Nature Education. Great Barrington: Orion Society.

Steiner, John. 2013. "Discussion: Climate Change in a Perverse Culture." In Engaging with Climate Change: Psychoanalytic and Interdisciplinary Perspectives, edited by Sally Weintrobe, 8084. London and New York: Routledge.

Sterling, Stephen R. 2001. Sustainable Education: Re-Visioning Learning and Change. Totnes: Green Books for the Schumacher Society.

Stevenson, Robert B., Justin Dillon, Arjen E. J. Wals, and Michael Brody. 2013. "The Evolving Characteristics of Environmental Education Research." In International Handbook of Research on Environmental Education, edited by Robert B. Stevenson, Michael Brody, Justin Dillon and Arjen E. J. Wals, 512-517. New York: Routledge.

Stevenson, Robert B. and Ian Robottom. 2013. "Critical Action Research and Environmental Education: Conceptual Congruencies and Imperatives in Practice." In International Handbook of Research on Environmental Education, edited by Robert B. Stevenson, Michael Brody, Justin Dillon and Arjen E. J. Wals, 469-479. New York \& London: Routledge.

Stoknes, Per Espen. 2015. What we Think about when we Try Not to Think about Global Warming: Toward a New Psychology of Climate Action. White River Junction: Chelsea Green Publishing.

"The Tbilisi Declaration. The World's First Intergovernmental Conference on Environmental Education." UNESCO and UNEP. 1977.

Tillich, Paul. 1952. The Courage to be. New Haven: Yale University Press.

Tillich, Paul. 1965. "Right to Hope." Neue Zeitschrift Für Systematische Theologie Und Religionsphilosophie 7 (3): 371-377.

Toh, Swee-Hin and Virginia Floresca Cawagas. 2010. "Transforming the Ecological Crisis: Challenges for Faith and Interfaith Education in Interesting Times." In Education and Climate Change. Living and Learning in Interesting Times, edited by Fumiyo Kagawa and David Selby, 175-196. London and New York: Routledge.

Välimäki, Jukka and Johannes Lehtonen. 2009. "Ilmastonmuutoksen torjuntaan tarvitaan johtajuutta." Kanava 6: 341-344. 
Van Wieren, Gretel. 2013. Restored to Earth: Christianity, Environmental Ethics, and Ecological Restoration. Washington, D.C: Georgetown University Press.

Wallace, Jennifer. 2007. The Cambridge Introduction to Tragedy. Cambridge: Cambridge University Press.

Webb, Darren. 2007. "Modes of Hoping." History of the Human Sciences 20 (3): 65-83.

Weintrobe, Sally. 2013a. "The Difficult Problem of Anxiety in Thinking about Climate Change." In Engaging with Climate Change: Psychoanalytic and Interdisciplinary Perspectives, edited by Sally Weintrobe, 33-47. London and New York: Routledge.

Weintrobe, Sally, ed. 2013. Engaging with Climate Change: Psychoanalytic and Interdisciplinary Perspectives. London: Routledge.

Weintrobe, Sally. 2013b. "On the Love of Nature and on Human Nature: Restoring Split Internal Landscapes." In Engaging with Climate Change: Psychoanalytic and Interdisciplinary Perspectives, edited by Sally Weintrobe, 199-213. London and New York: Routledge. Weissbecker, Inka, ed. 2011. Climate Change and Human Well-being: Global Challenges and Opportunities. New York: Springer.

Williston, Byron. 2012. "Climate Change and Radical Hope." Ethics \& the Environment 17 (2): 165-186.

Windle, Phyllis. 1995. "The Ecology of Grief." In Ecopsychology: Restoring the Earth, Healing the Mind, edited by Theodore Roszak, Mary E. Gomes and Allen D. Kanner, 126-145. San Francisco: Sierra Club.

Wuthnow, Robert. 2010. Be Very Afraid: The Cultural Response to Terror, Pandemics, Environmental Devastation, Nuclear Annihilation, and Other Threats. Oxford and New York: Oxford University Press.

Zeyer, Albert and Elin Kelsey. 2013. "Environmental Education in a Cultural Context." In International Handbook of Research on Environmental Education, edited by Robert B. Stevenson, Michael Brody, Justin Dillon and Arjen E. J. Wals, 206-212. New York \& London: Routledge.

\footnotetext{
${ }^{1}$ There is a problem in labeling people who wish to advance environmental matters as "environmentalists", because the use of the term is often related to identity politics. However, I use the term here for brevity.
} 